\title{
An ethical and aesthetic challenge: symbolic reparation and the construction of memory
}

\author{
Vera Vital-Brasil*
}

\section{Key points of interest:}

- Clínicas do Testemunho is a psychological reparation pilot project, which is of an experimental character and the first of its type to be subsidized by the Brazilian state.

- Testimony of survivors of torture experienced at the hands of the Brazilian state during and after the dictatorship in Brazil from 1964 to 1985 produces repercussions in the wider social context.

- From the point of view of the individual, testimony is not only a clinical tool for healing but also the construction of memory.

- From the point of view of society, testimony is an important part of the reparation process and forms an important role in the construction of collective memory and the foundation of democracy.

- It is recommended that similar projects are initiatied in other settings and countries.

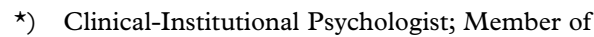
the Equipe Clinico-Político of Rio de Janeiro; Coordinator of the Clínica do Testemunho Project/Projetos Terapeuticos, Rio de Janeiro; Member of the Human Rights Commission of the Federal Council of Psychology (2014-2016);

\begin{abstract}
This article concerns the Clinicas do Testemunho, a pilot project carried out in Rio de Janeiro, which was supported by the Amnesty Commission of the Brazilian Ministry of Justice and was carried out between 2013 and 2015. It highlights how giving testimony can be a vehicle for psychological reparation and can help in the process of constructing individual and collective memory, as well as resistance. The article begins with a narrative about the dictatorship and the struggle for Memory, Truth, Justice and Reparation that followed, showing how psychological reparation emerged as one of the components of this process. Through the clinical experience, it highlights the effects of persecution and torture on subjectivity, and the use of clinical strategies and devices that produce changes in subjectification. It also highlights testimony as an important part of the reparation process and its role in the construction of memory and democracy.
\end{abstract}

Keywords: torture, testimony, reparation, transitional justice, disappearance, amnesty, memory

External Consultant of the Territorios Clínicos de la Memoria project (Argentina).

Correspondence to: veravitalbrasil@gmail.com 


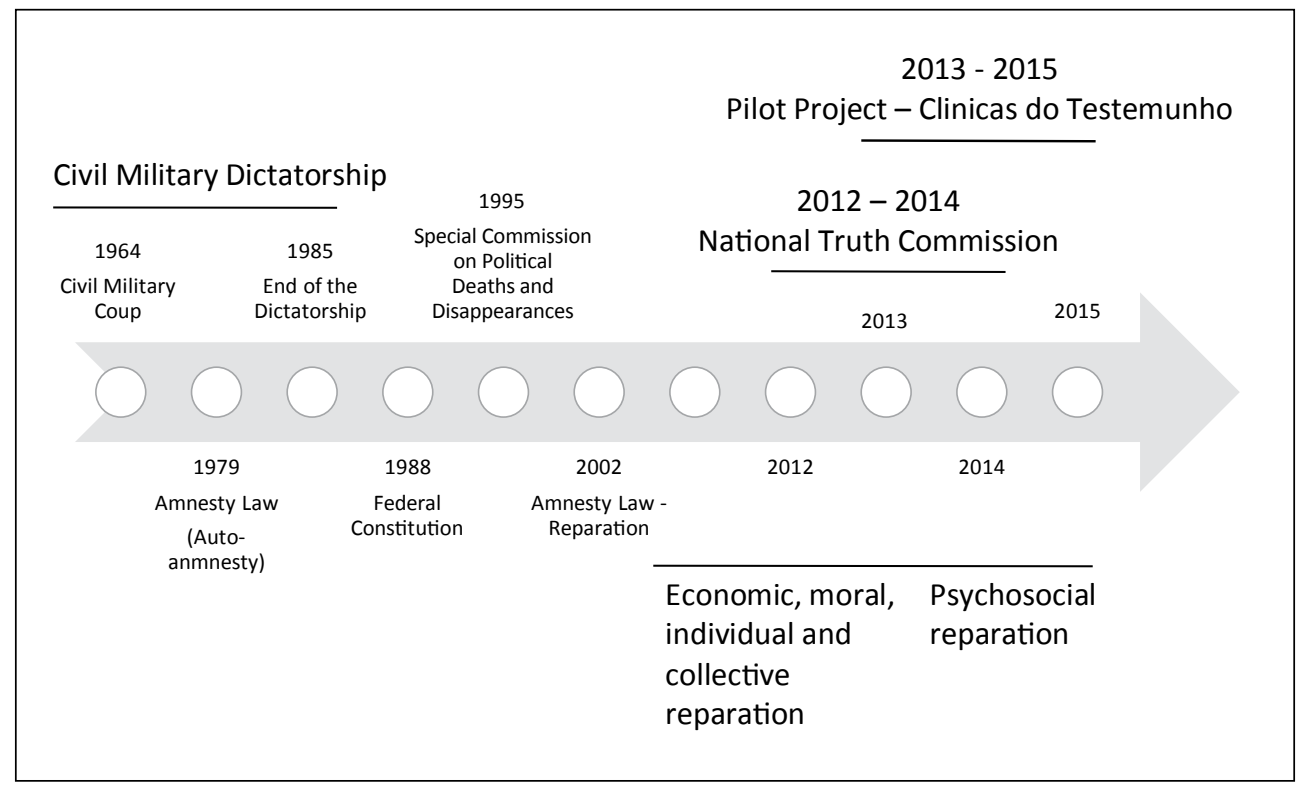

\section{Introduction}

"... I felt that the people who were present at the public hearing, those looking at me attentively and who heard my testimony, were talking to me, that they believed in me." The words above express surprise and emotion. They refer to a scene that had been experienced a few days before by a torture survivor at a public hearing organized by the State Truth Commission of Rio de Janeiro. These words had also been heard by a clinical psychological group, the Grupo de Construção de Testemunhos (Construction of Testimonies Group), one of the Clinica do Testemunho's activities. Breaking the silence of a violent past that occurred 40 years ago, F. spoke publicly about what had happened shortly before she turned 18 years old. While imprisoned and tortured, her two brothers were killed by the brutality of the agents of repression.

When the narrative's author reveals what she has repressed for so many years, the sphere of subjectivities is impacted. Therefore this act of testimony produces repercussions in the wider social context. Those who listen to the testimony see themselves entangled in the fabric of the story being told. Through the act of testimony, the story of an individual's life, which is simultaneously a part of and produced by the universe of barbarity, radiates to the common sphere. Through this process, the memory of dark times can be recuperated and shared. This is the symbolic value of words, how what is spoken is transferred to the collective and affects those who listen.

Clinicas do Testemunho is a psychological reparation pilot project, which is of an experimental character and the first of its type to be subsidized by the state. It is intended to help us to critically analyze the production of subjectivities; what it has meant for each individual. In order to do this, it is fundamental to examine, briefly at least, how the authoritarian state affects subjectivity with respect to the bodies of the regime's opponents and their relatives, as well as society as a whole. It is necessary, 
therefore, to present a retrospective on the struggle for human rights in order to situate the issue of symbolic reparation and the potential of the collective in this process (See Appendix for a timeline of key events).

\section{Politics of reparation in Brazil}

"Se podes olhar, vê. Se podes ver, repara." [If you are able to see, look. If you can look, take note.]

In political regimes that are organized in a vertical, dogmatic and authoritarian manner, maintaining themselves through strong repressive control, dominant forms of subjectivity tend to be reproduced. Beyond the force of authoritarianism, during the Brazilian dictatorship, these forms of subjectivization were solidified through social relations, guaranteeing that the damage caused endured. Throughout the long period of dictatorship spanning 21 years and in the years that followed, silence, amnesia and denial were fostered. Even directly after the dictatorship, the reasoning that predominated was not to look back; it was assumed that forgetting human rights violations and arbitrary action by the state would guarantee a promising future. This was a strategic message spread by political speeches and contemporary cultural expression through the media, to stifle silence imposed during the authoritarian regime and to create the space to forget.

Although some progress was achieved during the brief democratic regimes, basic principles of human rights were and are still not guaranteed. Challenged by that which was left behind, Brazil has not addressed all the measures which Transitional Justice shows to be necessary (Abrão \& Torelly, 2011; Gomez, 2014). It is undeniable that the scars left by institutionalized violence at the hands of the state are still apparent. Even the marks of the colonization of this continent remain visible. The brutal violence that the indigenous people of Latin America and the slaves brought from Africa were subjected to appears today through assassinations and/or is demonstrated by the miserable conditions of Brazilian prisons. As with the living remnants of the open wounds of slavery, the country is riddled with racism, a social trauma that until recently was denied and continues to produce new victims daily. The political, social and economic practices that were rooted in authoritarianism, social relations are tainted with discrimination, intolerance, prejudice, and profound inequality. These scars illustrate the weaknesses in our democracy, highlighting the need to make substantial strides to guarantee civil rights.

The Brazilian state belatedly recognized its responsibility for crimes against humanity carried out during that dictatorial period. Civil society's struggle to expose state violence and to bring to justice those who were responsible has only recently gained public attention but dates back many years. The demands of civil society organizations, especially relatives of those who were killed or disappeared and the survivors of those who were persecuted, opened the way for the affirmation of human rights specifically in the field of civil rights in Latin America, and later, the public recognition of the violations carried out by the authoritarian state. ${ }^{1}$ The pilgrimages of relatives to the barracks and prisons in search of information about their loved-ones had already begun during the authoritarian

1 We can highlight here the work of the movements Grupos Tortura Nunca Mais, Associações de Familiares de Mortos e Desaparecidos, and the support of the Comissão de Fustiça e Paz, and the National Press and National Bar Association (ABI and $\mathrm{OAB})$. 
regime. With the parties that were directly affected by the terror of the state as protagonists, these movements and other Latin American movements triggered the beginning of a process which has denounced gross violations perpetrated by state agents and called for the recognition of human rights. Consequently, in the last few decades, with the process of democratization, the assurance of human rights has broadened in several areas. The strength of this pressure, of sections of society crying out for justice, resulted in sowing the seed of change in public policy. Public policy changes were necessary to address violence in ethnicracial relations and discrimination, as well as intolerance regarding gender and police violence towards the most vulnerable groups of Brazilian society. This process, however, was slow-moving. Prior to the introduction of the new Federal Constitution in 1988, the response to the recognition of the violations suffered by victims was complete denial.

The creation of the Special Commission on Political Deaths and Disappearances $^{2}$ formed in 1995, 10 years

2 Created by the Law 9.140/45 that implemented the Comissão Especial [Special Commission], the Brazilian state recognized political deaths and enforced disappearances during the military dictatorship. In the 2017 publication "Direito à Verdade e à Memória" [The Right to Truth and Memory] produced by the National State Secretary of Human Rights, 136 political deaths and enforced disappearances were identified. In the Final Report of the National Truth Commission published in 2014 (which can be found here: http://cnv.memoriasreveladas. gov.br/index.php?option $=$ com content\&view $=$ article\&id=571), 434 political deaths and enforced disappearances were identified. Although the number of victims of the genocide of the indigenous population is not included in the final report, the Commission recognized but did not quantify this statistic. following the return to constitutional rule, was the first measure taken by the state to recognize crimes committed during the dictatorship. The Commission, based in the Presidential Secretary of Human Rights [Secretaria de Direitos Humanos da Presidência da República], has been responsible for the investigation of crimes against humanity, in particular political deaths and enforced disappearances, its mandate being to search for documentation, shed light on the truth and construct the collective memory on the violence perpetrated by the authoritarian regime.

Only years later, reparation policies became more extensive and driven by the Comissão de Anistia [Amnesty Commission] of the Ministério de Fustiça (Ministry of Justice) decreed by Law no. 10.559/2002. The Commission recognizes violations that occurred between 1946 and 1988, such as torture, imprisonment, exile, arbitrary dismissal, political disenfranchisement, among others, invoking political amnesty for victims of these acts.

It is worth noting that the Lei $d a$ Anistia [Amnesty Law ${ }^{3}$ decreed during the dictatorship period was at the time (1979) met with a wide campaign that occupied public spaces all over the country demanding "ample, universal and unrestricted Amnesty." There are, two "Amnesty" laws that incorporate different content, exposing the ambivalence with which the Brazilian state

3 The Lei da Anistia [Amnesty Law] 6.683/79, instead of embracing civil society demands, only gave partial amnesty to those who opposed the coup d'état. It allowed the return of exiles, freed some political prisoners while keeping some imprisoned (those accused of committing so called "blood crimes"), and protected those who ordered and carried out crimes against humanity. 
dealt and deals with its past. In the 1979 law, the concept of amnesty is that of "amnesia"; a state pardon for the crimes committed by those who opposed the oppressive regime of the civil-military dictatorship. Those responsible for the crimes against humanity perpetrated during the dictatorship were granted protection under this law as a strategy to conceal and deny crimes committed by state agents. The second amnesty law, approved in 2002, reverses the logic of the 1979 law, addressing reparation for victims of state violence. The 2002 law recognizes the right to resist a totalitarian state and exclusively grants protection for those that faced material, physical or psychological suffering due to state violence. The comprehensive reparation process is comprised of three types of reparation: (i) economic reparation, ${ }^{4}$ (ii) moral reparation, ${ }^{5}$ and (iii) individual and collective reparation through the construction of memory.

Reparation means that the state is recognized as a promoter of crime and persecution and is a complex concept. Connected to the survivor's suffering, it is a process comprised of several dimensions: judicial, political, economic, moral, symbolic and clinical. It is insufficient to consider separately, as solely a judicial or administrative initiative, or even merely an individual deed. The symbolic dimension is particularly valuable as it allows the emersion of new perceptions of victims' suffering, much of which has been frozen in time, and acknowledges society's collective experience in living through this terror.

Between 2007 and 2015, ${ }^{6}$ the Comissão da Anistia [the Amnesty Commission] created strategies to disseminate its work and further the construction of memory. One of the mechanisms the Amnesty Commission used was called the "Caravanas da Anistia" [Amnesty Caravans]. Beginning in 2008, this project toured several cities where violations were committed, hosting public sessions assessing claims by those petitioning for political amnesty. Another project, "Marcas da Memória" [Memory Marks], subsidized the creation of films, documentaries, plays, exhibitions, and publications utilizing artistic resources to depict the dimensions of the authoritarian period. These cultural exercises fortified the construction of collective memory, making amends through interrogating the present by exposing open wounds of the past. The Amnesty Commission considered psychological damage as an issue, accepting the task of amplifying reparatory measures, because it acknowledged the damaging effects of state violence on subjectivity and the lack of public policy on psychological reparation that could help those affected.

In 2012, a public bid was launched for a pilot project to provide clinical attention to victims and their families. The project, named "Clinicas do Testemunho", worked to create conditions to establish public policy on the psychological element of reparation. The project consisted of three key action points:

(i) the provision of clinical care for those granted amnesty and their families;

(ii) the provision of professional training to psychologists; and,

(iii) the production of information for the creation of future public policy.

$4 \quad$ Economic reparation refers to monetary compensation for the interruption of life plans.

5 Moral reparation refers to the issuance of an apology by the relevant authorities.

6 The Comissão de Anistia activities became

more limited in 2016 following the juridicalparliamentary-media coup d'état that removed then President Dilma Rouseff. 
Various clinical teams from around the country applied to participate in the project. The selection process considered regional diversity and the teams' expertise. The Amnesty Commission hoped to utilise the public selection process to mobilise civil society around the subject of psychological reparation and to consolidate partnerships with qualified teams. Four applicants ${ }^{7}$ were chosen, including the Equipe Clinico Politica ${ }^{8}$ of Rio de Janeiro.

The team from Rio de Janeiro has 20 years of experience in providing clinical care to those affected by state violence and in providing training to mental health professionals. Their application was developed with the nongovernmental organization Grupo Tortura Nunca Mais of Rio de Janeiro, whose projects were subsidized by international cooperation agencies. In 1999, the "Red Latinoamericana y del Caribe de Instituciones contra la Tortura, la impunidad y otras violaciones de los Derechos Humanos" [The Latin American and Caribbean Network of Institutions against Torture, impunity and other human rights violations] was created, and has also been supported by the International Rehabilitation Council for Victims of Torture. The clinical team's experiences in providing care for trauma victims informed the integration of specific points into the pilot project. These points included issues such as:

7 In addition to the Instituto Projetos Terapêuticos RJ project in Rio de Janeiro, Instituto Projetos Terapêuticos and Sedes Sapientiae from São Paulo, as well as the Associação Sigmund Freud from Porto Alegre were also chosen.

8 The Clinical Team in Rio de Janeiro was made up of seven professionals: four psychotherapists, one psychoanalyst, one psychiatrist, and one body therapist.
- The complexity of state terror and violence and the use of a transdisciplinary perspective of the clinical approach examined under an ethicalpolitical perspective.

- The relevance of the historical, social and political dimensions, as a constitutive part of subjectivity of each individual, emphasizing the production of subjectivities in permanent circulation of the socius (Guattari \& Rolnik, 1996).

- The team's clinical approach opposed the focus on the psyche as an entity isolated from social and political aspects and/or that which considers the family dynamic fundamental.

Moreover, for the clinical team it was clear that only the State could amend the damage because it was the agent of the violence. In addition, the team recognized the limits that a clinical instrument has without state support for memory, truth and justice. The first project in symbolic reparation was created for ex-political prisoners who had received amnesty, those who were in the amnesty process and relatives of those who were killed or disappeared during the dictatorship. ${ }^{9}$ It began in 2013 and went on until 2015.

To the benefit of the project, public debate on corresponding themes gained momentum with the launch of the first

9 In its constitutional mandate the Comissão de Anistia received reparation claims of those persecuted between 1946 and 1988. These claims were examined by the board, through the documents presented, who decided whether or not they were "anistiados politicos." The people attended to by the project were those who had already received amnesty and those who were still waiting for the board's decision. Up until 2012 more than 70,000 political amnesty requests were presented as the majority were granted and others were in the process of being evaluated. 
National Truth Commission and the 2014 commemoration of the 50-year anniversary of the civil-military coup. Although the public remained wary of the state's intentions in regards to the reparation initiative, the opportunity to break the silence on the suffering experienced was triggered. In this context, beyond documentation, the role of testimony became increasingly valuable in the investigations carried out by the National Truth Commission. Many individuals that were persecuted, former political prisoners and their relatives felt encouraged to testify. The sentiment spread throughout the country. Local committees and collectives comprised of former political prisoners and young, militant human rights activists were created to monitor the Commissions. The opportunity to break the silence unlocked the ability to verbalize victims' lived experiences. The psychological scars, illustrated through the clinical and public testimonies, that were produced by the totalitarian state remained visible even 50 years after the military coup d'état that instated the dictatorial regime.

In 2013, the Clinica do Testemunho of Rio de Janeiro developed various different types of services: individual clinical sessions, psychiatric sessions, groups, family sessions, physical therapy ${ }^{10}$ and accompaniment for those that testified in the National Truth Commission. The clinical team also organized a number of relevant activities, such as:

(i) trainings for mental health professionals in Rio de Janeiro and other Brazilian states ${ }^{11}$;

10 In total 135 participants were seen, 97 in group sessions and 38 individually.

116 workshops, in total 12 hours, carried out in Minas Gerais, Rio Grande do Sul, Rio de Janeiro, (ii) “Conversas Públicas" (Public

Discussions), an extended listening device to present and promote the psychological reparation proposal ${ }^{12}$; and,

(iii) produced information that could serve as reference for the creation of future public policy, specifically the production of a publication titled "Uma perspectiva Clínico Politica na reparação simbólica: a experiência da Clínica do Testemunho do Rio de faneiro" [A Clinical-Political Perspective in symbolic reparation: an experience of the Clinica do Testemunho in Rio de Janeiro].

In April 2013, the proposal was presented in a public discussion, which attracted approximately 100 participants, among them ex-political prisoners, relatives, civil society organizations, political parties, as well as mental health professionals interested in joining the team. Even after the first discussion, the manifestation of testimonies impacted attendees' perceptions about individuals' experiences under authoritarian rule.

\section{Testimony and symbolic reparation}

How can we take away the pain of those families whose relatives disappeared or were killed by the civil military dictatorship? How can we "give back" the time of those that faced imprisonment in abject conditions and/or were subjected to torture? How do we heal the scars of torture, the trauma of violence committed by agents of the state after so many years of silence? Is it possible to rectify atrocities that are certainly not capable of being rectified, such as death?

Memory, the construction of the present

in two stages, being 24 hours in each locality, involving 57 professionals.

12 In total 8 "Conversas Públicas", two in Belo Horizonte, three in Rio de Janeiro, one in Vitoria, and two in Porto Alegre, in total 381 people. 
through the happenings of the past, as well as the act of testifying, are part of clinical practices. In the clinical context, the psychotherapist receives the "extended testimony", the experience of one who listens to the testimony and to the suffering of the subject. Jean Marie Gagnebin (2006) affirms that the function of the "extended testimony" is that:

"They can hear the unbearable narration of another, not because of guilt or compassion, but because only by symbolic transmission, acknowledged despite and because of the unspeakable suffering, only by going back to the past in a reflexive way can we help not to repeat it forever, to venture to draft another story, to invent the present.” (p.57)

Those who experience violence first-hand become witnesses of their time. The figure of the witness became relevant for the first time during the Nuremberg Trials and later, due to the revelation of the horrors experienced and the oppressive and barbarous mechanisms in place, in Latin America. The testimonial narrative was key in giving visibility to the crimes against humanity, exposing what had been hidden and denied by repressors, and contributing to clarifying what happened. This narrative was also key in returning the witnesses' condition of being human and to once again feel part of humanity. A way to root out the injected evil of the limited experience of the concentration camps and prisons. The action of testifying opened the possibility of symbolic reparation, restoring the ability to feel, returning dignity to those that went through extreme conditions, through torture and cruel treatment in the position of objects, as disposable beings.

\section{Effects of torture}

In clinical work with survivors of torture and state violence, many varied subjective effects may be identified. Experiencing trauma and torture produces an isolating effect, in which silence overcomes the victim. In all its forms and with all its consequences, the amount of impact on an individual's psychological and physical being, as well as their social connections must be highlighted. Torture ruptures the bonds that connect the individual to the external world, affecting relationships between siblings, families, between peers, resulting in a painful process.

Perpetrators not only seek to force the subject to provide information, confess their actions, and/or to betray their networks, but also to dominate the victim, quash their individualism and overpower the individual. The aftereffect of torture is silence (Sironi, 2011). Under the mandate of terror, the isolating experience of torture was produced. When victims remember the terror they experienced, they often remain silent, dreading the panic attacks that frequently occur when recalling the trauma they experienced. The fear of not being able to transmit, of not being understood by those that listen to them, of hurting others by expressing the horrors they experienced, results in the silence and isolation of the individual with their family members and their social groups. Families, marked by the incommunicability of what happened, live the pain and the angst of the trauma, which transmits to subsequent generations (Cardoso \& Mourão, 2015; Herrera, 2015; Kolker, 2009; Vital-Brasil, 2009). Torture survivors, however, can break the legacy of isolation through testimony. The act of providing testimony may allow for a new direction in a victim's life, that before was confined to the individual and that thwarted social bonds. Given the complexity of the process of testifying, how can society feasibly break the silence following so many years of denial, without actively listening to victims' experiences? How can memory be 
reconstructed about a period of time that has been suppressed through silence and collective amnesia?

As we are dealing with actions of men, who historically are inserted in politics by groups, that use the production of what is evil to politically dominate others, an ethical political instrument is necessary in this process of access to the memory of these dark times. Showing the importance of a "professional" listener, whether it be a mental health professional or the public authorities responsible for psychological reparation. Testimony refers to truth and this is what gives it consistency. This exposed truth isn't what was actually lived; it is what was left of the experience that happened (Deleuze, 1974); of what was left in the memory as a fragmented recollection of the facts.

Fabiana Rousseaux, a psychoanalyst who has accompanied those who have testified in cases about crimes against humanity in Argentina, claims that a testimony is a production "of fiction and of writing" (Rousseaux, 2015, p.107). It is precisely through this psychological endeavor to construct the truth that the witness is able to produce new meanings for what happened, find new expressions and directions. Providing testimony is not the repetition of what is remembered, but an eruption of a memory, of something that resided there, where the paradoxical form wasn't accessed or verbalized (Rousseaux, 2015).

"On being arrested I received a passport to hell and this hell has never ended."

This statement was expressed by a torture survivor after they began clinical therapy with the Clinica do Testemunho Project in Rio de Janeiro. The patient referred to the continuation of their suffering and the memories of the past that have accompanied them throughout their life. Throughout the treatment, this statement and others began to gain validity. Months later, having found an outlet for their pain, an internet-based initiative titled "Cartas ao Vento" was created. The initiative, created by those involved in the Clinica do Testemunho project, consisted of anonymous letters to the general public penned by torture survivors, narrating their traumatic experiences.

To expose traumatic experiences, it is necessary to create politically-sound clinical strategies that take into account elements and conditions that can facilitate expressions of suffering. In the Clinica do Testemunho Project of Rio de Janeiro, we sought to create strategies that supported the construction of narratives and other expressions for the lived events, helping to transform the position of victim to that of witness by bringing together a psychological dynamic which is usually suppressed or blocked by trauma. In addition to the variety of group treatment methods used, ${ }^{13}$ other mechanisms were created to permit the interaction with the diverse collectives involved in memory and truth issues.

One of this project's objectives was to find methodological approaches to create public policy on the basis of clinical findings, a strategy used in the introduction of experimental mechanisms. Guidelines included: the promotion of broad participation; the creation of innovative devices that help to free words and/or expression about traumatic experiences; the introduction of activities that increase exchange; the promotion of more communicability about what had been confined to the private environment.

13 Reception Group, the Construction of Testimonies Group, the Therapeutic Group, Special Groups, Body Therapy Group, the Women's' Groups 
These guidelines were put in place in favor of the production of meaning and the reconstruction of a social fabric.

\section{Conversas Públicas or Public Conversations:}

Accordingly, mechanisms, such as "Conversas Públicas", were developed to allow for the dissemination of the project. This activity mobilized individuals to share their experiences during the authoritarian period. Participants included former political prisoners, relatives, human rights activists, members of political parties and psychologists. Inspired by the name of the project, participants began to provide public testimonies. Rodrigo Blum claims that in the "Conversas Públicas", "the boundaries between what is public, what is clinical, and what is conversation become so close that they become the same territory" (Blum, 2015, p.36). The spoken word crossed the different universes of experiences, facilitating the construction of a collective memory.

\section{Collective testimony mechanisms: The project}

also created collective testimony mechanisms exclusively for those enrolled in the project. These mechanisms were created with the intention of promoting inter-generational integration project participants, facilitating the space for victims to explore the motives of their relative's silence in regards to what occurred during the period of terror, for example. Is was shown through the project's impact assessment that people who had never been together were united through the activity's meetings, including retired and persecuted military personnel and former political prisoners, as well as their children and grandchildren. Their interaction enabled these individuals to discover, through different struggles and acts of resistance, the effects that violence had had on the course of people's lives and on their physical bodies.
Participants and therapists also participated in public hearings, seminars, plenaries and public activities, so that listening to testimonies would be a shared experience, transmitted to the socio-political sphere; a shared sphere of citizenship.

\section{Communication network: A new} communication network and a new form of agency emerged. A new form of social and political 'protaganism' was created through the act of giving testimony (becoming protagonists of their own stories). The experience of both listening and of being heard mobilized the creative methods of providing testimony. The use of poems, drawings, texts, photographic exhibitions and dramatizations was born out of this experience. Revealing what a pencil line or a gesture can say beyond that of the written or spoken word, various forms of expressions were built on the aesthetic power of what words alone cannot express.

Furthermore, new collectives were born out of the Clinica do Testemunho project beyond the clinical meetings comprised of persecuted low-rank soldiers, survivors of the Army's Central Hospital, as well as the children and grandchildren of survivors, the killed and disappeared during the dictatorship. The acceptance and recognition of their pain through statemandated psychological reparation in the form of psychological treatment cut across these groups of primary and secondary victims. This permitted the transition of relatives from their supportive position to those affected and further into becoming a formalized collective, the "Grupo de Filhos e Netos por Memória Verdade fustiça" (Group of Children and Grandchildren for Memory of Truth and Justice). Through this process they are able to reclaim their own narratives on the effects of violence, an issue no longer 
exclusive to their parents or grandparents, allowing them to become protagonists in the larger struggle. ${ }^{14}$

In total 44 people who signed up to the project, accompanied by therapists, gave testimony in various public hearings of the National and State Truth Commissions. They were heard by both the public and by the authorities under state mandate.

After clinicians from the project accompanied those who testified for the Commissions, as was set out in the original project proposal, a partnership with Rio Janeiro's State Truth Commission ${ }^{15}$ was consolidated. This led to other people becoming involved, such as the members of the Commission themselves. Their team, due to the impact of the witness accounts, was shaken by the intensity of the violence, and asked for support from the clinical team to ensure a qualified listening process.

\section{Conclusion}

"A testimony, as it confronts humanity with its heinous parts and draws attention to the ethical position that consists of transmitting the unspeakable, became the privileged method to narrate an experience of what is not transferable precisely by those who have tried to convey it." (Koltai, 2015, p. 149)

Due to its methods, crimes against humanity affect both the individual and society at large, revealing the effects of human cruelty

14 About the diversity of the aesthetic productions and the political actions see the publication: "Uma experiência Clínico-Política na reparação simbólica: a Clínica do Testemunho do Rio de faneiro." Available at: http://www.justica.gov. br/central-de-conteudo/anistia/anexos/livro-online-2.pdf.

15 Rio de Janeiro's Truth Commission mandate was from March 2013 to November 2015. More information available at: http://www.cev-rio.org. br/. that reverberate through society. Torture simultaneously destroys the dignity of both the tortured and the torturer.

Torture interrupts victims' life plans, altering a victim's destiny. Through testimony, victims expose their wounds to everyone.

The reparation process does not give back the time that was lost in torture chambers or reinstate the lives of those who were killed or disappeared. It is possible and necessary, however, as a legacy for following generations, to reclaim the narrative of those whose lives were uprooted by the hand of state violence. Through the intermediary of testimony, we can experience the struggles of historical moments and understand what this meant for each individual during this period in order to reconstruct the fabric of collective memory.

In the clinical context, a testimony is a driver of new subjectivities for the testifier, and simultaneously, a driver in the construction of a collective memory that is imprinted on the common realm. Through the testimony, the link between those affected by state violence, individually and collectively, can be reconstructed.

Being listened to is fundamental to those giving their testimony, the individual who risks narrating in words their tragic experience. Through this process, they can reconnect the threads of an interrupted life and reintegrate into the community and rebuild relationships. The action of listening, in which the effects unfold between those who are touched by the testimonial narrative can be moved from otherness, empowered by the ethical commitment to Memory, Truth and Justice.

During the Clinica do Testemunho project in Rio de Janeiro, patients and clinical staff appreciated the role of the project in pioneering the ability to re-position themselves in relation to their past and open themselves up to the present in order to become protagonists of resistance struggles 
against arbitrary policies. The clinical team provided a range of tools and mechanisms in which words gained different forms of impact. The recognition of witnesses' words in the mandate of the Truth Commissions can be understood on two levels: to recognize and to be recognized. In their final reports, the Truth Commissions expressed the importance of psycho-social reparation for the damaged caused by state violence. Clinical teams in various states asked the Comissão da Anistia for an expansion of the project. The Brazilian state maintained its commitment in the development and consolidation of a symbolic reparation policy, creating a new public call in 2015 in which additional clinical teams were incorporated into psychological reparation initiatives.

In recent years, the Brazilian state has made important steps in strengthening democracy through the development of human rights, memory, truth and reparation policies. The work of the Truth Commissions launched a larger conversation on violations during the dictatorial regime, the extent of which society previously knew little about. Their final reports included recommendations for the Brazilian state, suggesting a number of measures, such as the creation of institutional policy; suggestions which require action.

Today, the Brazilian justice system continues to provide amnesty to torturers and facilitates impunity for the current police forces. The country still lives under the protection of the 1979 interpretation of the Amnesty Law, despite recommendations having been made by the Truth Commissions and by Inter-American Court. ${ }^{16}$ The lack

16 Gomes Lund case, November 2010, which determined that crimes against humanity should be investigated and the perpetrators should be of reinterpretation of this law indicates the conservative political bias that has prevailed in the judicial field, establishing a serious limitation for necessary changes within the democratic process. Moreover, the lack of recognition for the crimes and violations committed in the past by the Armed Forces and the police have led to a pattern of violence and killing within the most vulnerable societal groups, primarily those who live in the slums, black people, the indigenous populations and the imprisoned.

Today, the world is confronted by a conservative and regressive movement. Brazil is not immune to this trend. Brazil's fragile democracy, in 2016, suffered a judicial-political-parliamentary coup d'état with the decisive support of the media that removed the president without her having committed any crime; a regression on rights that had been conquered after years of struggle. The implementation of the so-called "economic adjustment policies" has seen a significant increase in the levels of unemployment and social economic inequality. Police violence has also increased, primarily toward the most vulnerable groups of society. Intolerance is exposed through culture, where fundamentalism dominates. Fascism is manifesting itself all over the country, even those who have parliamentary mandates praise torture and revere notorious torturers. Public authorities break with constitutional principles shamelessly or with no qualms of possible sanctions. The Amnesty Commission, a state organ, responsible for reparation, is currently at risk of extinction. The attack on these principles and conventions, to which the Brazilian state is signatory to, speaks to the core of Brazilian democracy's fragility.

\footnotetext{
held responsible by the Brazilian state.
} 
We can infer that if the state had invested more earlier on and with more effort in the construction of human rights, enabling an advance in Transitional Justice measures, current levels of violence would not be so high. With more established ethical principles and with a stronger sense of citizenship, society's capacity to respond to this setback could have been halted as would the tendencies to reverse the social and political conquests of the last decades. Democracy and human rights are inseparable. They coincide to create a historical context where the level of "democracy" is variable, depending on the respect and the guarantees provided by the state's public administration. Reyes Mate affirms, above all, that, "there is no justice without the memory of injustice," and that, "the philosophical response to the irreversible injustice caused to the victims is to keep it alive in the memory of humanity, we cannot say it has been dealt with until the past has been accounted for" (Mate, 2009, p.22).

Injustices should be remembered so that they are not repeated. Although memory can be considered a necessary political condition, it is insufficient to stop human barbarity from happening again. Keeping the memory about injustices of the past alive, however, is an enormous contribution to the construction of an ethical dimension that has a critical edge. It is an important contribution for those that gave testimony to find new places of belonging, to construct ethical benchmarks for future generations, as well as for the development of a common agenda in the pursuit of justice.

\section{Acknowledgements}

The author would like to thank Amy Jo Westhrop, an invaluable colleague who contributed to the translation into English.

\section{References}

Abrão, P. \& Torelly, M. (2011) Democratización y Derechos Humanos: compartiendo experiencias de América Latina. In: Fusticia Transicional. Manual para América Latina. Centro Internacional para la Justicia de Transición, ICTJ. Comissão de Anistia/MJ. pp. 23-31. Brasília \& Nueva York.

Blum, R. (2015) Conversa Clínica Pública: o público testemunho. In: M. Silva \& I. Mercadante (Orgs.), Travessia do silencio, testemunho e reparação (pp. 3138). São Paulo: Instituto Projetos Terapêuticos, Comissão da Anistia, Ministério da Justiça. www. justica.gov.br/central-de-conteudo/anistia/anexos/ travessia_final.pdf.

Cardoso, C., \& Mourao, J. (2015) Notas sobre o ato de comunicar-se. In C. Cardoso, $\mathrm{M}$. Felipe \& V. Vital-Brasil (Orgs.), Uma perspectiva clínico-política na reparação simbólica: Clínica do Testemunho do Rio de faneiro (pp. 111120). Brasilia: Projetos Terapeuticos RJ, Comissão da Anistia, Ministério da Justiça.

Deleuze, G. (1974) A lógica do sentido. São Paulo: Perspectiva.

Gomez, J. M. (2014) A Justiça Transicional e o imprevisível jogo entre a política a memória e a justiça. In M.R. Ansari, F. Pradal \& A. Westhrop (Orgs.), 50 anos da Ditadura no Brasil: Memória e Reflexões (pp. 71-80). Rio de Janeiro: ISER.

Guattari, F. \& Rolnik, S. (1996). Micropolitica: Cartografias do Desejo. Petrópolis: Vozes.

Gagnebin, J. M. (2006). Lembrar escrever esquecer. São Paulo: 34 Ltda, p. 57.

Herrera, C. (2015) Enredos na transmissão: construção do testemunho entre gerações. In M. Silva \& I. Mercadante (Orgs.), Travessia do silencio, testemunho e reparação (pp. 85-98). São Paulo: Instituto Projetos Terapeuticos, Comissão da Anistia, Ministério da Justiça.

Instituto Projetos Terapêuticos (2015) Uma experiência Clínico-Política na reparação simbólica: a Clínica do Testemunho do Rio de faneiro. Comissão da Anistia, Ministério da Justiça. Brasilia.

Kolker, T. (2009) Problematizaciones ClínicoPolíticas acerca de la permanencia y transmisión generacional de los daños causados por el terrorismo de Estado. In: (Orgs) B. Brinkman; M. Lagos; V. Vital-Brasil \& M. Scapusio. Daño Transgeneracional: Consecuencias de la Represión Politica en el Cono Sur. (pp. 253-284) Santiago de Chile: Cintras, Eatip, GTNM-RJ, Sersoc. Edición Unión Europea.

Koltai, C. (2015) Do relato ao testemunho. In: (Orgs.). In M. Silva \& I. Mercadante (Orgs.), Travessia do silencio, 
testemunho e reparação (pp. 147-149). São Paulo: Instituto Projetos Terapêuticos, Comissão da Anistia, Ministério da Justiça.

Mate, M. (2009) Fundamentos de una filosofía de la memoria. In: B. Ruiz, fustiça e Memória: para uma crítica ética da violencia (pp. 17-50). São Leopoldo: UNISINOS.

Rousseaux, F. (2015) La asistencia a víctimas de delitos de lesa humanidad hecha política pública. Del acompañamiento en los juicios contra el terrorismo de Estado a la creación del Centro Fernando Ulloa. In: El ex detenidodesaparecido como testigo de los juicios por crímenes de lesa humanidad. (pp. 93-110). Buenos Aires: Fundación Eduardo Luis Duhalde.

Sironi, F. (2011) Carrascos e Vitimas. Psicologia da Tortura. São Paulo: Terceira Margem.

Vital-Brasil, V. Efectos transgeneracionales del terrorismo de Estado: entre el silencio y la memoria. In: Daño Transgeneracional: consecuencias de la represión política en el cono sur. (Orgs.) B. Brinkman; M. Lagos; V. Vital Brasil \& M. Scapusio. pp. 289-327. Santiago de Chile: Cintras, Eatip, GTNM-RJ, Sersoc, Edición Unión Europea. 